\title{
Quantifying the impact of land degradation on crop production: the case of Senegal
}

\author{
B. G. J. S. Sonneveld ${ }^{1}$, M. A. Keyzer ${ }^{1}$, and D. Ndiaye $^{2}$ \\ ${ }^{1}$ Centre for World Food Studies (SOW-VU), Vrije Universiteit, De Boelelaan, 1081 HV Amsterdam, the Netherlands \\ ${ }^{2}$ Centre de Suivi Ecologique, Fann-Residence, BP, 15532 Dakar, Senegal \\ Correspondence to: B. G. J. S. Sonneveld (b.g.j.s.sonneveld@ vu.nl)
}

Received: 28 April 2015 - Published in Solid Earth Discuss.: 22 June 2015

Revised: 12 December 2015 - Accepted: 14 December 2015 - Published: 21 January 2016

\begin{abstract}
Land degradation has been a persistent problem in Senegal for more than a century and by now has become a serious impediment to long-term development. In this paper, we quantify the impact of land degradation on crop yields using the results of a nationwide land degradation assessment. For this, the study needs to address two issues. First, the land degradation assessment comprises qualitative expert judgements that have to be converted into more objective, quantitative terms. We propose a land degradation index and assess its plausibility. Second, observational data on soils, land use, and rainfall do not provide sufficient information to isolate the impact of land degradation. We, therefore, design a pseudo-experiment that for sites with otherwise similar circumstances compares the yield of a site with and one without land degradation. This pairing exercise is conducted under a gradual refining of the classification of circumstances, until a more or less stable response to land degradation is obtained. In this way, we hope to have controlled sufficiently for confounding variables that will bias the estimation of the impact of land degradation on crop yields. A small number of shared characteristics reveal tendencies of "severe" land degradation levels being associated with declining yields as compared to similar sites with "low" degradation levels. However, as we zoom in at more detail some exceptions come to the fore, in particular in areas without fertilizer application. Yet, our overall conclusion is that yield reduction is associated with higher levels of land degradation, irrespective of whether fertilizer is being applied or not.
\end{abstract}

\section{Land degradation in Senegal}

Land degradation is a worldwide process that affects all five continents (Masto et al., 2015; Xu and Zhang, 2014; Thomas et al., 2015; Yan and Cai, 2015; Wang et al., 2013; Jafari and Bakhshandehmehr, 2013; Cerdà and Lavee, 1999; Bai et al., 2013). The process of land degradation deprives the quality of natural resources and impairs directly on human society (Izzo et al., 2013) through loss of ecosystem goods and services. Moreover, land degradation changes hydrological and biogeochemical cycles in the earth system and hampers development of new soil, or pedogenesis (Berendse et al., 2015; Keesstra et al., 2012; Brevik et al., 2015). Annually land degradation costs an estimated USD 40 billion worldwide (ELD Initiative, 2013), and degraded land is costly to reclaim (LADA, 2015). Consequences of land degradation are severe especially for poorer societies that do not have the available means to compensate loss of land productivity (e.g. Rajashekhar Rao, 2015) and suffer from the created land scarcity, food insecurity, and damaged ecosystems. This also holds for sub-Saharan Africa where already in the late 19th and early 20th centuries warnings were issued about severe risks of land degradation (Chevalier, 1900; Stebbing, 1935), as colonial governments had been introducing commercial agriculture, with natural vegetation replaced over large surfaces by monocultures of cash crops. By now these risks have turned into rather dramatic erosion and a consequent threat to food security, biodiversity, and economic development, especially in the poorest parts of the continent where farmers lack access to fertilizer and other inputs (Lal, 2011).

Senegal is a case in point. Sharp increases in dust deposition of terrigenous sediments could be related to land 
degradation processes in Senegal that started in the 1840s, after the promotion by the French colonial power of groundnut cultivation (Mulitza et al., 2010). The incessant demand for agricultural land eliminated the last stretches of original wooded savannas and open woodlands in the early 1900 s (Boahene, 1998). What remained were agricultural parklands dominated by a small range of Acacia species (Tschakert and Tappan, 2004) that no longer could protect the soils against wind and water erosion and resulted in less favourable physical and chemical properties in the top soil (Kairé, 2003). During the first half of the 20th century, development of a network of roads and processing centres, and establishment of railroads enabled further expansion of groundnut cultivation, which from 1960 (the year of independence) until 1980 also benefited from domestic support through state-dominated cooperatives and from preferential export arrangements with France, the main customer. The European Union has pursued this relationship until present within the Lomé Convention and Cotonou Agreement (European Commission, 1999; Bergtold et al., 2005).

This resulted in more intensive forms of agriculture, while demand for fertile land gradually came to exceed availability (Mortimore et al., 2005), which gave rise to Senegal's first large wave of rural-urban migration in the period 1971-1980 (Mbow et al., 2008). Reform policies undertaken in the 1980s and implemented as the Structural Adjustment Programme reduced the state involvement but had detrimental effects on soil fertility management as fertilizer subsidies were abolished, and even the application of locally produced phosphorus became too expensive for Senegalese farmers to use (Speirs and Olson, 1992).

An expert judgement-based inventory (Sonneveld, 2003; Omuto et al., 2014) under the Land Degradation in Dryland Areas (LADA) project (FAO/UNEP) shows that currently $34 \%$ of the national territory and $58 \%$ of the agricultural areas are affected by a degradation process. Sonneveld et al. (2012) tested the consistency of these expert judgements by a cross-comparison of mapping units with identical characteristics for annual rainfall, soil suitability, slope, population density, and livestock density. The study concluded that experts had a high consistency in their judgement and gave reliable assessment on the degree of land degradation. The experts indicated that land degradation seriously impairs agricultural capacity and the quality of ecosystem services. Particularly alarming is the fact that the observed increase in the rate of land degradation affects $26 \%$ of the total land area and $40 \%$ of the agricultural areas against 5 and $6 \%$ with improving trends in land quality, respectively. The LADA inventory also reveals that types, causes, and impacts of land degradation are diverse. While the Senegalese government has recognized the severity of these problems (Declaration of Abuja; IFDC, 2006, Senegal Emergent Plan in ADB, 2014), the planning of actual interventions seems to be constrained by lack of more than very general knowledge about the actual impact of land degradation on agricultural production under the various conditions prevailing in Senegal.

Yet, establishing a relationship between land degradation and productivity loss is not an easy task, for various reasons (Vieira et al., 2015). First, our available crop yield statistics refer to a spatial unit (polygons that combine land use and districts) for which the experts gave an assessment on degree and extent of land degradation but without more specific indication of where crops are cultivated, and where land degradation is prevalent. Second, there are various confounding factors at play that impact on both land degradation and crop production (Ferreira et al., 2015). Isolating these is especially difficult for Senegal because there are no historical records available on fertilizer application. While an experimental field trial can for given observed biophysical conditions simulate various intensities of land degradation and for every intensity measure the resulting crop yield, under non-experimental conditions, treatment effects cannot be isolated in this way, and estimation biases can hardly be avoided, since correlation between these conditions is inevitable and observed fertilizer application cannot be corrected for in a satisfactory manner. Instrumental variable estimation (Nkonya et al., 2008) and propensity score matching (Kassie et al., 2008) are no exception to this.

Here we opt for a direct matching approach, whereby we measure differences in crop yields (outcomes) at various levels of land degradation (treatment intensities) under the same external circumstances (conditions), proceeding in two steps. First, we compile a representative land degradation assessment for our spatial entities combining expert assessments on degree and extent of land degradation in a single land degradation factor that can be related to corresponding crop production figures. Second, we compare crop production for sites that share similar biophysical and socio-economic characteristics, but one site suffers from land degradation and the other site not. To assess the sensitivity of this relationship for the number of shared conditions, we extend the number and degree of detail of the, largely categorical, explanatory variables referring to these conditions.

There is a tradeoff here. The finer explanation will have fewer observations in every treatment class, but it will account for more variables, hopefully reducing the correlation of remaining unobserved variables with the treatment intensity (i.e. land degradation). Hence, it maps out in a categorical setting what would for ordinary regression on continuous variables be the tradeoff as obtained for a larger number of variables, between good fit and better significance of coefficients. Our assertion will be that relationships that change little under this variation are presumably relatively stable to other, so far unobserved factors as well.

The paper proceeds as follows. Section 2 describes the data used in this study. Section 3 re-interprets expert judgements so as to relate the degree and extent of land degradation to crop production. Section 4 assesses the effect of land degradation on crop yields. Section 5 concludes. 
Table 1. Data, geographical resolution, and source.

\begin{tabular}{lll}
\hline Data & Resolution & Source \\
\hline Expert assessments on land degradation & Polygons & Sonneveld et al. (2010), CSE (2008) \\
Administrative subdivision (2009) & Polygons & CSE (2008) \\
Administrative subdivision (2005) & Polygons & CSE (2008) \\
Natural resources: soils, altitude classes, land use & Polygons & CSE (2008) \\
Slope & Grid 1 1 km & FAO/IIASA (2000) \\
Production systems & Polygons & CSE (2008) \\
Population density & Grid 1 1 km & Nelson (2004) \\
Livestock (cattle, buffalo, sheep, and goats) & Grid $1 \times 1 \mathrm{~km}$ & FAO (2007) \\
Presence of primary, secondary, and tertiary roads & Segment & Van Wesenbeeck and Merbis (2012) \\
Distance to primary, secondary, and tertiary roads & Grid $1 \times 1 \mathrm{~km}$ & Van Wesenbeeck and Merbis (2012) \\
Millet production $\left(\mathrm{kg} \mathrm{ha}^{-1}\right)$ & District & FAO (2006) \\
\hline
\end{tabular}

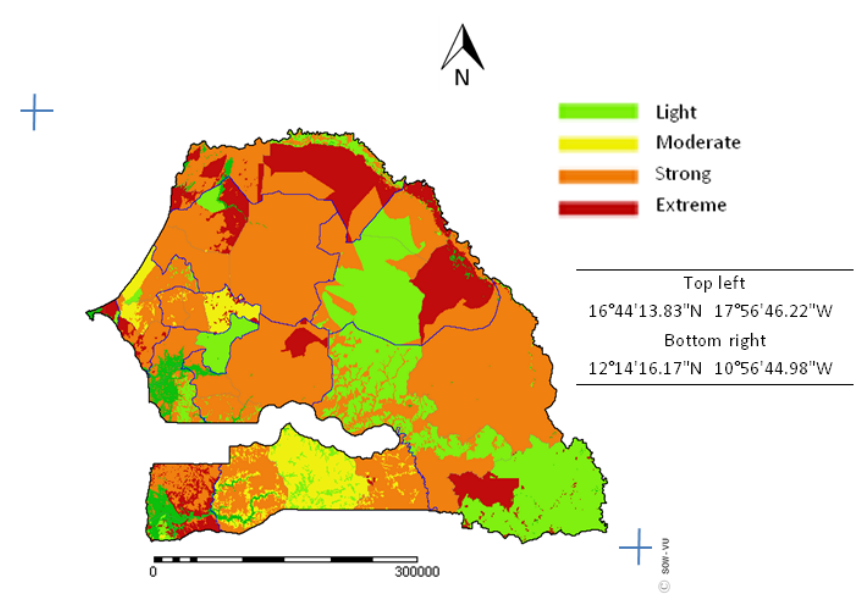

Figure 1. Average degree of land degradation.

\section{Material and methods}

Table 1 summarizes data attributes, geographical dimensions, and sources.

Land degradation assessments: the land degradation inventory has been based on judgements of experts who identified for each of the 33 Senegalese districts and per production system area shares and the degree and rate of land degradation. Degree and rate of land degradation are expressed in ordered qualitative classes. Figure 1 presents the degree of land degradation by district and production system zone.

Administrative data: we combine two administrative subdivisions - an (older) administrative subdivision of 30 units that is used as a georeference for district statistics on agricultural production and the current administrative subdivision of 33 units which serves as a spatial reference for production systems, land degradation assessments, and population.

Base resource maps: the two major components of the base resource map provided four rainfall classes $(1=<200$; $2=200-400 ; 3=400-700 ; 4=>700 \mathrm{~mm}$ ) and four soil
Table 2. Production system, area (in hectare), and share of total land area in percentage.

\begin{tabular}{lrr}
\hline Production system & Area (ha) & Share of total \\
\hline Peri-urban & 245234 & 1.2 \\
Irrigated & 200572 & 1.0 \\
Floodplains & 160068 & 1.0 \\
Agro-pastoral & 2541424 & 12.7 \\
Rainfed & 1891141 & 9.4 \\
Transhumant & 3357948 & 16.8 \\
Forestry & 7678003 & 38.3 \\
Nature reserve & 2995748 & 15.0 \\
No assessment made & 962385 & 4.8 \\
\hline
\end{tabular}

suitability classes $(1=$ unsuitable; $2=$ moderately suitable; $3=$ suitable; $4=$ very suitable).

Production system map: the nine production systems, their area in hectare, and a share of the national total are presented in Table 2.

The population density map was obtained from the UNEP database (Nelson, 2004) and upscaled for each district for the year 2005 with data from the Agence Nationale de la Statistique et de la Démographie, in Senegal.

The tropical livestock unit map was derived from FAO (2007). Global density maps were given for cattle, goats, and sheep at $1 \times 1 \mathrm{~km}$ scale. These animals comprised $86 \%$ of the total livestock expressed in tropical livestock unit (TLU), which allows the comparison of grazing demand of different species in a common unit. As detailed data per district are missing we upscaled the total TLU nationwide proportionally to the prevailing total TLU densities that were derived from the cattle, goats, and sheep.

Roads: the Food Atlas of Africa project (van Wesenbeeck and Merbis, 2012) provided the segments on primary, secondary, and tertiary road presence. The segments were gridded on the $1 \times 1 \mathrm{~km}$ grid. Using the ILWIS distance operator (ILWIS Academic version 3.3) we calculated for each pixel the distance to the primary, secondary, and tertiary roads. 
Table 3. NPK applications $\left(\mathrm{kg} \mathrm{ha}^{-1}\right)$ for millet groundnut, rice, and cowpea.

\begin{tabular}{|c|c|c|c|c|c|}
\hline Region & AEZ & Millet & Groundnut & Rice & Cowpea \\
\hline Dakar & Niayes & 95 & & & \\
\hline Diourbel & Centre Nord Bassin Arachidier & 4 & 15 & & \\
\hline Fatick & Sud Bassin Arachidier & 4 & 28 & & \\
\hline Kaolack & Sud Bassin Arachidier & 3 & 28 & & \\
\hline Kolda & Basse et Moyenne Casamance & 207 & 6 & 0 & \\
\hline Kolda & Sénégal Oriental/Haute & 83 & 28 & & \\
\hline St Louis & Fleuve & 0 & & 247 & \\
\hline St Louis & Zone Sylvo-pastorale & 0 & & & 0 \\
\hline Tambacounda & Sénégal Oriental/Haute Casamance & 83 & 28 & & \\
\hline Thiès & Centre Nord Bassin Arachidier & 4 & 28 & & \\
\hline Thiès & Niayes & 94 & 28 & & \\
\hline Ziguinchor & Basse et Moyenne Casamance & 186 & 6 & 0 & \\
\hline
\end{tabular}

Source: IPNIS (www.fao.org/ag/agl/agll/ipnis/index.asp); last access: November, 2009.

Crop production data at district level were for rice, maize, millet, sorghum, cassava, cowpeas, groundnut, and sesame, derived from FAO (2006; Agromaps). The crops represented $93 \%$ of the total cultivated area (FAOSTAT, 2005). Areas and production levels were upscaled to the national level to represent the entire cultivated area; yield data remained the same as reported in the Agromaps database.

The procedure for estimating the yield by grid cell is as follows. We distribute the district output by crop over the cultivated land at grid level, relying on a constrained scaling procedure (Keyzer and Pande, 2007), which adjusts gridlevel output until it meets the district total, within grid-level bounds. We set these bounds so as to offer a range around a reference yield (output divided by cultivated land) multiplied by grid-level area. The reference yield was given to pixels that were assigned to production system zones where crop production is made possible. Furthermore, we accounted for the spatial variation of the soil quality by multiplying reference yields for soils "unsuitable", "not very suitable", "moderately suitable", and "suitable", with $0.2,0.6$, 0.8 , and 1.0, respectively, analogue to the AEZ methodology (FAO/IIASA, 2000). For our analysis we will concentrate on the yields of millet, as this crop is the most widely cultivated and avails of spatial fertilizer statistics.

Fertilizer: data on fertilizer applications were derived from the Integrated Plant Nutrition Information System (IPNIS; www.fao.org/ag/agl/agll/ipnis/index.asp). The IPNIS database provides data on NPK fertilizer and organic fertilizer at province level and by major Agro-ecological zone. The data were complete only for millet and groundnut, data for two other reported crops (rice and cowpea) were sparse while no information was given for other crops. Table 3 summarizes the total of inorganic and organic NPK applications.

Georeferencing spatial data: all spatial data were georeferenced on a $1 \times 1 \mathrm{~km}$ grid. Specifications of the coordinate systems are given in Sonneveld et al. (2010). Polygons of the natural resource base map and the production system map that were smaller than $1 \mathrm{~km}$ were mapped on this grid map with a nearest neighbour operation, using areas in the attribute tables to indicate a proportional share of the grid area.

Creation of a land degradation index: to compare the impact of land degradation on crop yields between different sites, we relate crop yields to a land degradation index that combines area shares and degradation classes as provided by the experts of the LADA exercise.

To provide a general impression of the relationship, we conduct an exploratory analysis of non-parametric regression using a smoothing method that interpolates point observations on crop yields for the area shares and degree of land degradation so as to reveal the prevalent patterns between the variables. Specifically, we apply a mollifier mapping, a flexible form of curve-fitting that follows the data closely and compensates for the lack of a priori knowledge of an explicit parametric functional form (Keyzer and Sonneveld, 1998) of the land degradation index. The mollifier program implements a kernel density regression to show estimated values in 3-D graphs in a surface plot against two independent variables. Furthermore, the program generates descriptive statistics about the reliability of the estimate and depicts these in the default mode as colour shifts in the surface plot and ground plane, respectively - alternatively, the incidence of other covariates can be shown in these dimensions. We apply to the tool to gradually zoom in on the reliable areas of the data domains. Since fertilizer emerges as an important explanatory variable, we included it as a covariate.

Climatic conditions are accounted for by expressing the crop yield as a ratio of actual to potential yield that is defined as a climate-constrained crop output under optimal soil conditions. As noted earlier, the assessment attributes to every production system zone one or several degrees of degradation with a corresponding area share. To isolate degree- 


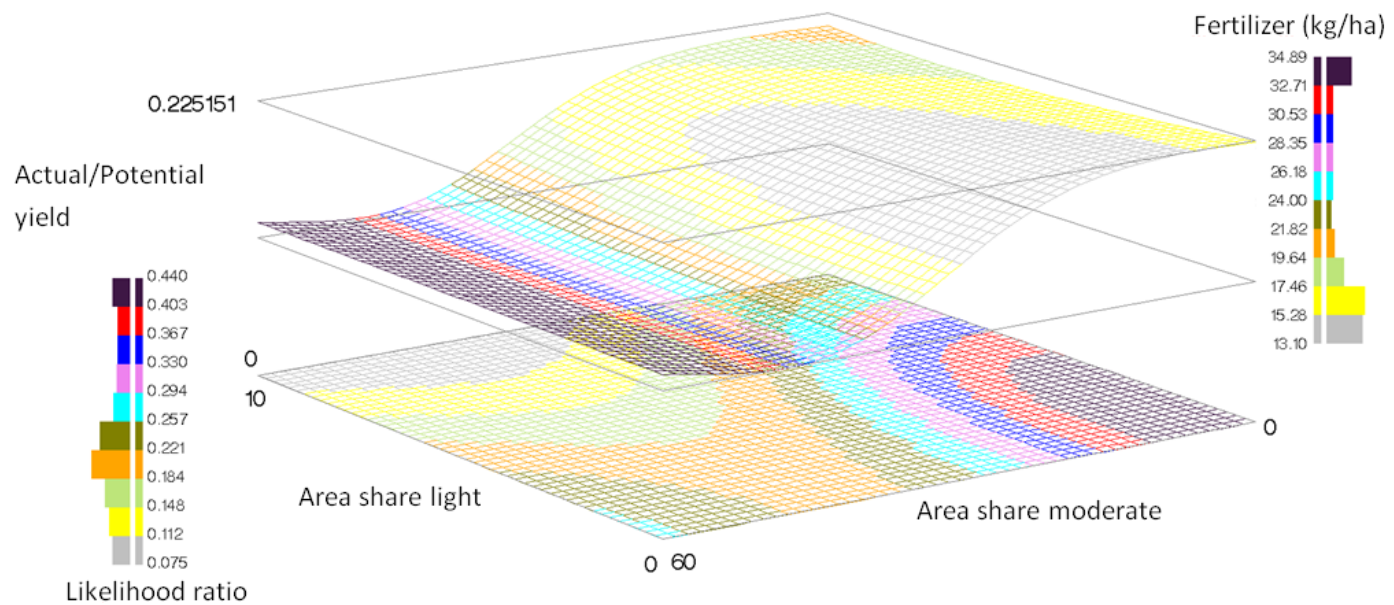

Figure 2. Yield ratio (actual / potential yield) against area share under light and moderate degradation; covariates: fertilizer applications and likelihood ratio.

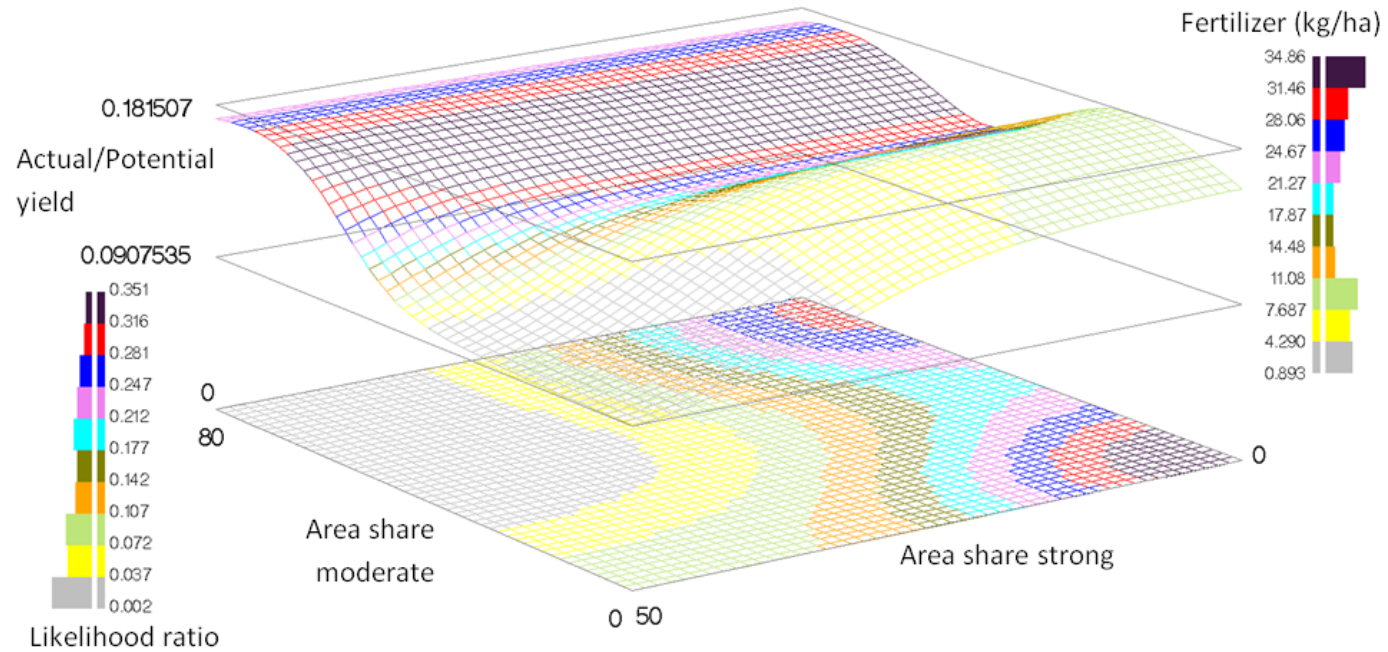

Figure 3. Yield ratio (actual / potential yield) against area share under moderate and strong degradation; covariates: fertilizer applications and likelihood ratio.

specific effects, we select observations with area shares that are higher than $75 \%$ for the dominant degradation degree.

Figure 2 shows the results for "light" and "moderate" degree of land degradation. The fertilizer applications appear as colour shift in the surface curve, while the observation density appears in the ground plane. The southeast-northwest axis shows an increasing area share of the "light" degradation class. In this direction we see a small increase of crop yield for higher area shares. Rising area shares for the "moderate" class are found along the northeast-southwest axis and show a rapid decline of the crop yield. There is, however, a slight recovery at higher area shares, which correspond to larger fertilizer applications. We further note that the higher observation densities are concentrated around the lowest area shares.
Next, Fig. 3 shows increasing area shares for the "moderate" and "strong" classes along the southeast-northwest and northeast-southwest axis, respectively. Crop yields decline rapidly for the "moderate" class to its lowest levels at around $50 \%$ of the area share but rise sharply in areas with high fertilizer applications. In areas with low fertilizer supplies crop yields decline with increasing area shares of the "strong" degradation, similarly to the "moderate" class. This suggests that "moderate" and "strong" degradation classes have similar impacts on millet yield while the impact of the "light" degradation is definitely lower. This leads us to define an aggregate index of degradation types that attributes twice the weight to area shares of "moderate" and "strong" degradation. The "severe" degree of degradation was reported only twice, and no clear response to yield ratio could be made. Assuming that "severe" degradation is an exceptional case we 
Table 4. Variables and encoding of categories used to make uniform sites.

\begin{tabular}{llr}
\hline Variable & Encoding of categories & Place in code \\
\hline Rainfall & $1=<200 ; 2=200-400 ; 3=400-700 ; 4=>700 \mathrm{~mm}$ & 1 \\
Soils & $1=$ unsuitable; $2=$ not suitable; $3=$ moderately suitable $;$ = suitable & 2 \\
Slope & $1=$ no slope; $2=$ undulating & 3 \\
Population density & $1=<600 ; 2=600-9000 ; 3=>9000 \mathrm{p} \mathrm{km}^{-2}$ & 4 \\
TLU density & $1=<21 ; 2=21-32 ; 3=>32 \mathrm{TLU} \mathrm{km}^{-2}$ & 5 \\
Fertilizer use & $1=<50 ; 2=50-150 ; 3=>150 \mathrm{~kg} \mathrm{ha}^{-1}$ & 6 \\
Access markets* & $1=1$. cat. $<10 ; 2=2$. cat. $<10 ; 3=3$. cat. $<10 ; 4=>10 \mathrm{~km}$ & 7 \\
\hline
\end{tabular}

* Access to markets expressed as distance to road categories.

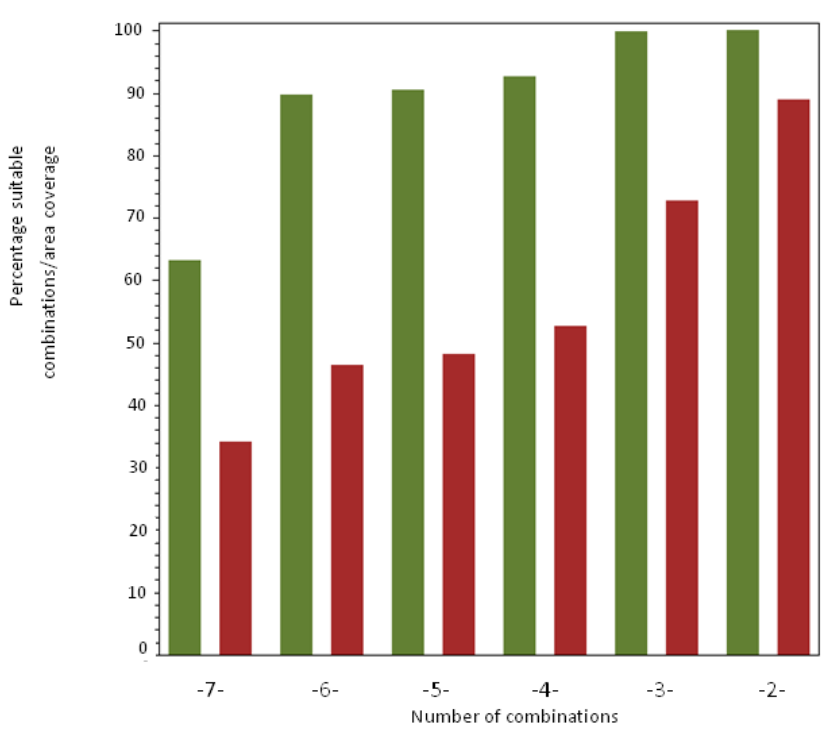

Figure 4. Percentage area coverage (green bar) and available combinations for pairwise uniform sites (red bar) defined by number of selected variables.

weigh its area share four times. Finally, the weighted values were normalized to let the range of the land degradation index fluctuate between 0 and 1 .

We acknowledge that the created land degradation index cannot be tested in full, yet combining classes and area shares in a single land degradation index has been used in many other peer-reviewed studies (Leiwen et al., 2005; Pace et al., 2008; Sonneveld and Dent, 2009), which gives us, jointly with our empirical results, sufficient confidence to apply the index for our analysis.

\section{Results and discussion}

We are now ready to analyse the effect of land degradation on crop production by comparing crop yields for sites that have similar circumstances pairing one with land degradation and one without it. We account for the occurrence of confounding factors by testing if this relationship is sensitive to the

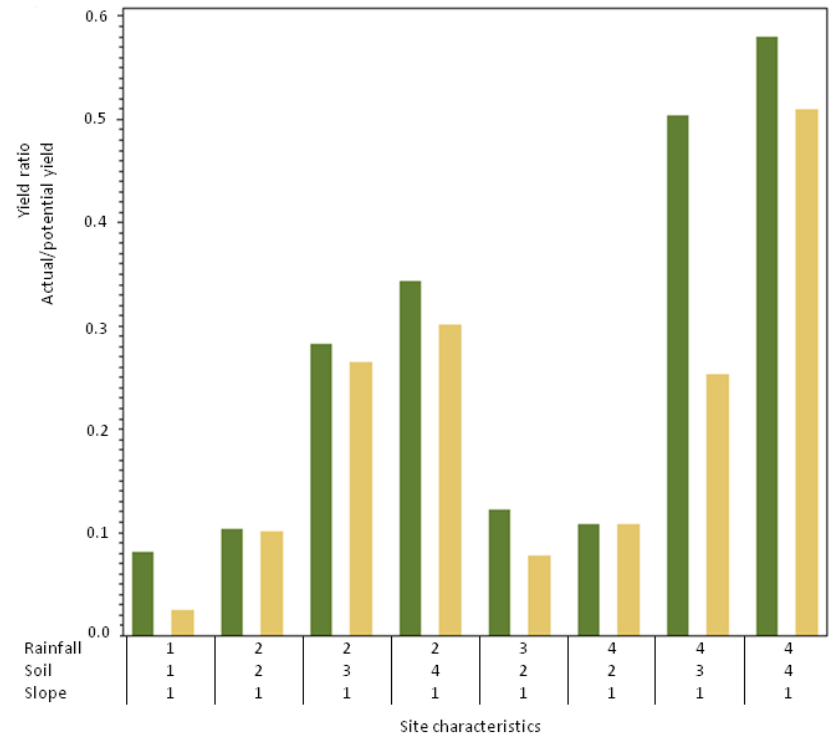

Figure 5. Comparing yields under "low" (green) and "severe" (light brown) degradation for uniform sites defined by three variables (rainfall, soil, and slope). Codes on $x$ axis for rainfall are $1=<200$; $2=200-400 ; 3=400-700 ; 4=>700 \mathrm{~mm}$; for soils $1=$ unsuitable; $2=$ not suitable; $3=$ moderately suitable; $4=$ suitable; for slope $1=$ no slope $; 2=$ undulating.

level of detail that is used to describe these circumstances. Hence, we gradually expand the number of explanatory variables hopefully reducing the correlation of remaining unobserved variables with the treatment intensity (i.e. land degradation and the bias in the estimation of the treatment effect). We suppose that once we find a stable relationship - that is no major change in yield effect after an extension of the list of explanatory factors - the relationship has become insensitive to unobserved factors (errors) and, consequently, that the bias has been sufficiently eliminated.

To describe these circumstances, we use three up to seven categorical variables as were identified in the geographical profile to create uniform sites. For these circumstances, we distinguish only two "treatment" levels, "low" and "severe", depending on whether they are below or above the 0.1 thresh- 

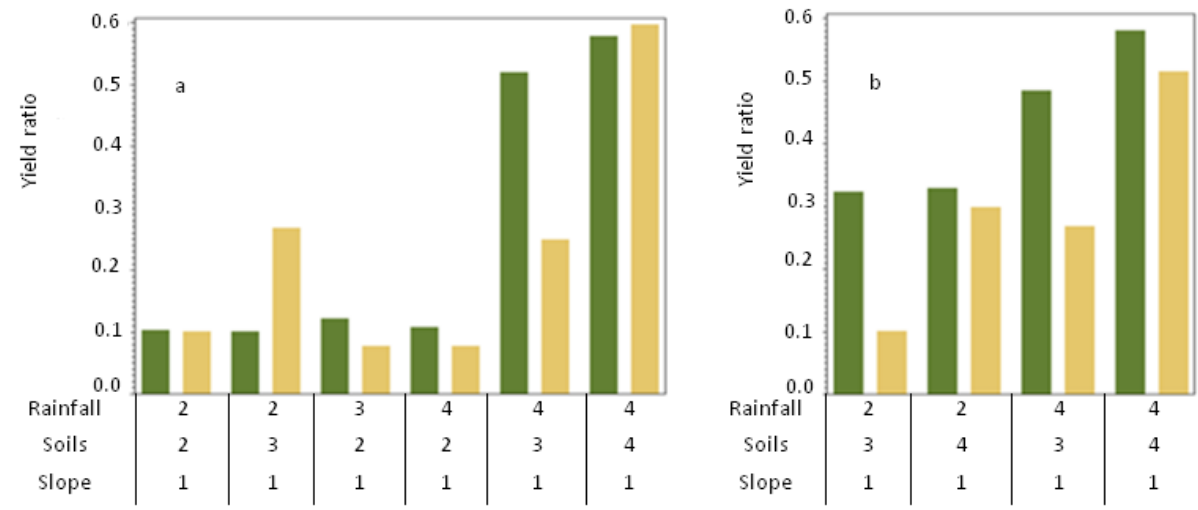

Site characteristics

Figure 6. Comparing yields under "low" (green) and "severe" (light brown) degradation for uniform sites defined by three variables (rainfall, soil, and slope) for "low" (a) and "moderate" (b) fertilizer applications. Codes on $x$ axis for rainfall are $1=<200 ; 2=200-400 ; 3=400-700$; $4=>700 \mathrm{~mm}$; for soils $1=$ unsuitable; $2=$ not suitable; $3=$ moderately suitable; $4=$ suitable; for slope $1=$ no slope; $2=$ undulating.

old point of the land degradation index. From the available combinations we selected those that occupy more than $10 \%$ of the area of a production system zone for which a land degradation assessment was available. Table 4 lists these seven variables and their class categories. The last column shows the place within the seven-digit code that is used to characterize the sites. A zero in this code means that this characteristic is not considered for the combination.

The selection of the number of variables for crossing seeks to strike a balance between accuracy and policy relevance. Use of many variables reduces the effect of unobserved variables but will rapidly increase the number of combinations. There will be more observations without a match in this case and hence reduces representativeness of the estimation. Conversely, with fewer variables accuracy of comparison will be less but the number of matches higher. Figure 4 illustrates the tradeoff, by plotting the percentage of combinations that could be compared for two land degradation conditions, and their area share is plotted against the number of variables used for crossing. The seven variables combined comprise $36 \%$ of the registered combinations while the two combined variables cover almost $90 \%$; in between we find a more or less linear increase of successful combinations under a decreasing number of selected variables. Concerning area share, differences are less pronounced. The seven variables combined cover an area share of $64 \%$, while other combinations report $89 \%$ or higher shares. Hence our assessment compares yields under "low" and "severe" degradation conditions for sites that are defined by combinations of three, four, and finally seven variables.

Figure 5 shows the pairwise comparison of average yields for "low" (green bars) and "severe" (sandy brown bars) land degradation at uniform sites defined by a combination of three variables (rainfall, soil, and slope). In all cases, lower yields are reported for "severe" degradation, varying from declines of less than 1-66\%, with an average of $25 \%$. Yield drops are most pronounced for low rainfall regimes and unsuitable soils, as well as for the combination of high rainfall and moderately suitable soils. Thus, we do not detect any definite relationship between severity of yield decline and specific combinations of rainfall, soil, and slope.

Figure 6 shows the comparison for sites defined by combining four variables (rainfall, soil, slope, and fertilizer). As we observed in Sect. 3, fertilizer can mitigate land degradation effects on yield and we decided to separate the pairs for "low" (Fig. 6a) and "moderate" (Fig. 6b) fertilizer applications. For low fertilizer applications, four out of the six combinations show a declining yield under "severe" land degradation, varying from 3 to $52 \%$ with an average of $30 \%$. The two cases with higher yields had "moderately suitable" and "suitable" soils. This might indicate that the productivity of better soils is not yet affected. However, we cannot exclude that other factors like soil conservation activities affect the outcome as well. In case of moderate fertilizer applications, we obtain in all six cases a decline in yield that varies from 9 to $69 \%$ with an average of $33 \%$. This is remarkable as the non-parametric estimation in Sect. 3 seemed to indicate that fertilizer has a compensating effect on land degradation. Yet, this more refined comparison tells us that land degradation effects cannot be mitigated by fertilizer. The solution might be more complex than merely applying more fertilizer, as some studies point to micronutrients (Voortman, 2010), while others clearly indicated a nitrogen deficiency (Saito et al., 2013). Furthermore, restoring phosphorus and potassium is not an easy task as the soils will first restore their buffer capacity and will not release a steady flow of nutrients until they reach new equilibrium.

Finally, we discuss the pairwise comparison, at sites that have seven variables in common (rainfall, soil, slope, population, TLU, fertilizer, and markets). For low fertilizer ap- 


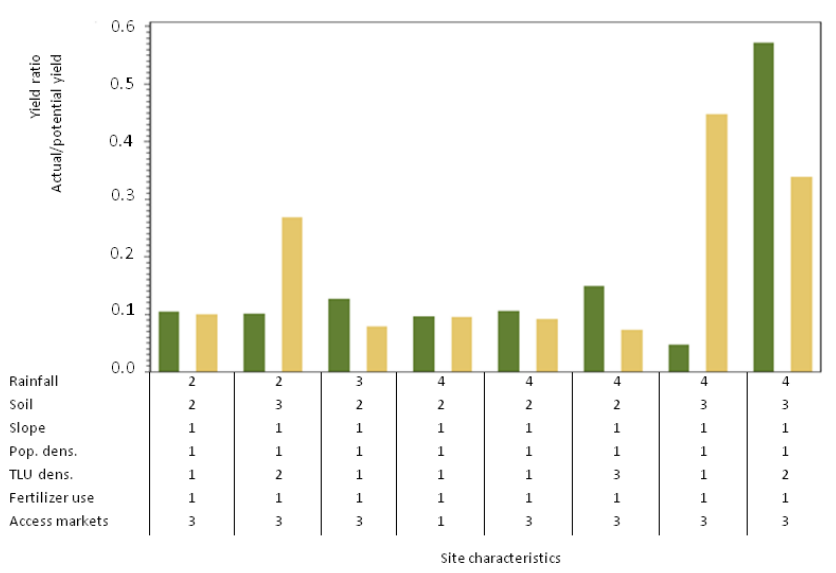

Figure 7. Comparing yields under "low" (green) and "severe" (sandy brown) degradation for uniform sites defined by six variables (rainfall, soil, slope, population, TLU, markets) for "low" fertilizer applications. Codes on $x$ axis for rainfall are $1=<200$; $2=200-400 ; 3=400-700 ; 4=>700 \mathrm{~mm}$; for soils $1=$ unsuitable; $2=$ not suitable; $3=$ moderately suitable; $4=$ suitable; for slope $1=$ no slope ; $2=$ undulating; for population density $1=<600$; $2=600-9000 ; 3=>9000 \mathrm{p} \mathrm{km}^{-2}$; for TLU density $1=<21$; $2=21-32 ; 3=>32 \mathrm{TLU} \mathrm{km}^{-2}$; fertilizer use $1=<50 ; 2=50$ $150 ; 3=>150 \mathrm{~kg} \mathrm{ha}^{-1}$; and for access to markets $1=1$. cat. $\operatorname{road}<10 \mathrm{~km} ; 2=2$. cat. $\operatorname{road}<10 \mathrm{~km} ; 3=3$. cat. $\operatorname{road}<10 \mathrm{~km}$; $4=>10 \mathrm{~km}$.

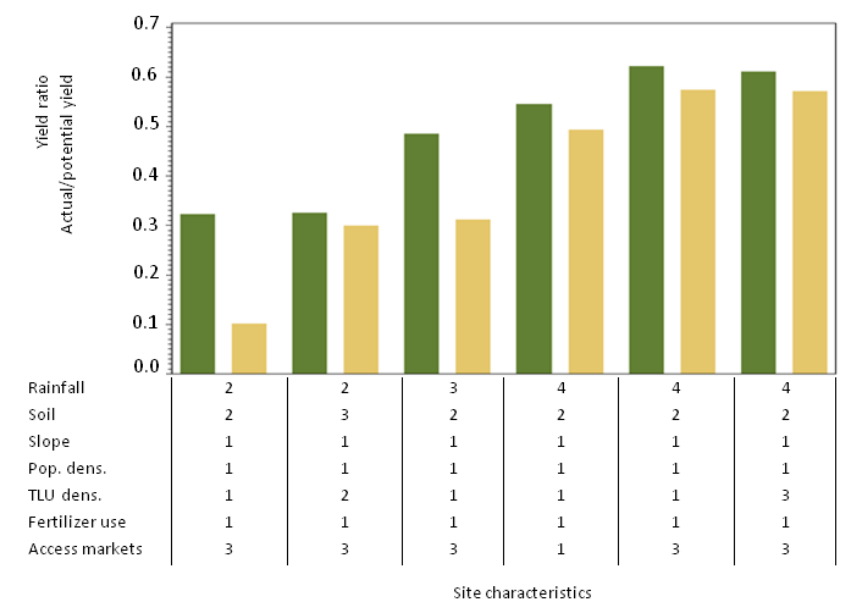

Figure 8. Comparing yields under "low" (green) and "severe" (sandy brown) degradation for uniform sites defined by six variables (rainfall, soil, slope, population, TLU, markets) for "moderate" fertilizer applications. Codes on $x$ axis for rainfall are $1=<200$; $2=200-400 ; 3=400-700 ; 4=>700 \mathrm{~mm}$; for soils $1=$ unsuitable; $2=$ not suitable; $3=$ moderately suitable; $4=$ suitable; for slope $1=$ no slope; $2=$ undulating; for population density $1=<600$; $2=600-9000 ; 3=>9000 \mathrm{p} \mathrm{km}^{-2}$; for TLU density $1=<21$; $2=21-32 ; 3=>32 \mathrm{TLU} \mathrm{km}^{-2}$; fertilizer use $1=<50 ; 2=50$ $150 ; 3=>150 \mathrm{~kg} \mathrm{ha}^{-1}$; and for access to markets $1=1$. cat. $\operatorname{road}<10 \mathrm{~km} ; 2=2$. cat. $\operatorname{road}<10 \mathrm{~km} ; 3=3$. cat. $\operatorname{road}<10 \mathrm{~km}$; $4=>10 \mathrm{~km}$. plications (Fig. 7), six out of the eight combinations show a declining yield under "severe" land degradation compared to the "low" level. Average yield decline for these six cases was $25 \%$, varying from 1 to $51 \%$. The two cases where higher yields are reported for "severe" degraded land correspond to better soils. However, one site, also endowed with "suitable" soils, shows declining yields for severe degraded areas. As noted earlier, this would suggest that better soils also have higher resistance against land degradation, albeit that other unobserved effects might be at play as well. The reason that productive soils are more resistant against degradation processes like water (Stanchi et al., 2015) and wind erosion (Herrick and Beh, 2015) is closely related to prevailing aggregate stability (Colazo and Buschiazzo, 2010) that determines important soil production properties like infiltration and permeability while protecting soils against dispersive water and wind forces (Jozefaciuk and Czachor, 2014; Geng et al., 2015). Organic matter that acts as a binding agent and nucleus in the formation of aggregates is the most important component of soil aggregate stability. Therefore, most cultivation techniques aim to optimize the soil organic matter through (zero-)tillage techniques (Costa et al., 2015; Singh et al., 2015), planting of native tree species (Tesfaye et al., 2014), mulching (Mwango et al., 2014), and land use systems (Araya et al., 2010). These activities are not observed in our database but influence the soil organic matter levels at surface and deeper horizons; moreover, the magnitude of variation is also shaped by specific pedogenic processes (Kukal et al., 2014). Hence, with the choice of our approach to test the stability of the relationship between land degradation and crop yield under an increasing level of detail, we hope to have controlled sufficiently for these confounding variables that otherwise might bias the estimation.

Yet, emphasizing the role of better soils and their resistance to land degradation is always worthwhile. Globally they cover only $3 \%$ of the land but produce $40 \%$ of the food and $90 \%$ of cereals. As regards the sites with moderate fertilizer applications (Fig. 8), we find declining yields for degraded soils that vary from 7 to $69 \%$ with an average of $23 \%$ for all sites. Here also, the moderate fertilizer applications cannot compensate for reduction in yield due to land degradation. Absence of historical records on fertilizer application obstructs a more direct evaluation of impacts and nutrient dynamics at every location. Yet, the lower yields on degraded areas with fertilizer applications are presumably caused by the long-term depletion of $\mathrm{P}$ and $\mathrm{K}$ stocks that are not easily compensated for through fertilizer volumes and mixes that were commonly applied. For example, currently applied $72 \mathrm{~kg} \mathrm{ha}^{-1}$ NPK for groundnuts is lower than recommended rates of $150 \mathrm{~kg} \mathrm{ha}^{-1} \mathrm{NPK}$ and $200 \mathrm{~kg} \mathrm{ha}^{-1}$ for gypsum (Thuo et al., 2011; Ntare et al., 2008).

A follow-up study might consider including information on land conservation practices applied at the sites, so as to allow for comparison of sites with and without such interventions, other circumstances remaining equal. For this, vari- 
ables of two kinds would need to become part of the data set: (1) specific conservation techniques that are tailored to the biophysical characteristics and land use systems, and (2) features of the institutional setting, which might otherwise remain a source of confounding factors, and are known to have been decisive for past success and failure of sustainable land management programmes (Bouma, 2008). Inclusion of these variables would allow for identification of the most advisable interventions and hence contribute to more tangible targeting of environmental measures, in line with the recently signed Partnership for Action on Green Economy (UNEP, 2014).

\section{Conclusions}

Two important conclusions can be drawn from this study. First, the land degradation index based on a combination of qualitative expert judgements and area shares affected by land degradation summarizes key information indicating that higher values correspond to lower crop yields in the way one would expect on the basis of literature. Second, a negative effect of land degradation could be established in qualitative, descriptive terms using a pairwise comparison with a number of shared characteristics. The results show that "severe" land degradation levels are being associated with declining yields as compared to similar sites with "low" degradation levels. The sensitivity to confounding factors was tested by conducting the matching at different level of detail for shared characteristics, until a stable relationship was obtained. As we zoomed in with more detail about shared characteristics, some exceptions came to the fore, particularly in areas without fertilizer application. Yet, overall we conclude that yield falls with land degradation, irrespective of whether fertilizer is being applied or not. Thus, intervention is called for to arrest further damage to physical soil properties and avoid further depletion of soil nutrients. At the same time, lack of information seems to be a major hurdle and more research is urgently needed to identify remedies.

Acknowledgements. This research was sponsored by the FAOGEF-UNEP Land Degradation in Dryland Areas (LADA) project. The authors like to thank FAO counterparts Freddy Nachtergaele, Sally Bunning, and Riccardo Biancalani for useful comments on an earlier draft.

Edited by: A. Cerdà

\section{References}

ADB: Senegal Economic Outlook, African Development Bank Group, available at: http://www.afdb.org/en/countries/ west-africa/senegal/senegal-economic-outlook/ (last access: August 2014), 2014.

Araya, A., Keesstra, S. D., and Stroosnijder, L.: Simulating yield response to water of Teff (Eragrostis tef) with FAO's AquaCrop model, Field Crops Res., 116, 196-204, doi:10.1016/j.fcr.2009.12.010, 2010.

Bai, X. Y., Wang, S. J., and Xiong, K. N.: Assessing spatialtemporal evolution processes of karst rocky desertification land: indications for restoration strategies, Land Degrad. Dev., 24, 4756, doi:10.1002/ldr.1102, 2013

Berendse, F., van Ruijven, J., Jongejans, E., and Keesstra, S.: Loss of plant species diversity reduces soil erosion resistance, Ecosystems, 18, 881-888, doi:10.1007/s10021-015-9869-6, 2015.

Bergtold, J., Norton, G., and Brewster, C.: Lom'e to Cotonou conventions: trade policy alternatives for the Senegalese groundnut sector, Agr. Econ., 33, 315-323, 2005.

Boahene, K.: The challenge of deforestation in tropical Africa: reflections on its principal causes, consequences and solutions, Land Degrad. Dev., 9, 247-258, 1998.

Bouma, J. A.: Voluntary cooperation in the provision of a semipublic good: Community-based soil and water conservation in semi-arid India Tilburg: CentER, Center for Economic Research, the Netherlands, 145 pp., 2008.

Brevik, E. C., Cerdà, A., Mataix-Solera, J., Pereg, L., Quinton, J. N., Six, J., and Van Oost, K.: The interdisciplinary nature of SOIL, SOIL, 1, 117-129, doi:10.5194/soil-1-117-2015, 2015.

Cerdà, A. and Lavee, H.: The effect of grazing on soil and water losses under arid and mediterranean climates, Implications for desertification, Pirineos, 153-154, 159-174, 1999.

Chevalier, A.: Les zones et les provinces botaniques de l'Afrique Occidentale Française, C. R. Hebd. Acad. Sci., 130, 1205-1208, 1900.

Colazo J. C. and Buschiazzo, D.: Soil dry aggregate stability and wind erodible fraction in a semiarid environment of Argentina, Geoderma, 159, 228-236, 2010.

Costa, J. L., Aparicio, V., and Cerdà, A.: Soil physical quality changes under different management systems after 10 years in the Argentine humid pampa, Solid Earth, 6, 361-371, doi:10.5194/se-6-361-2015, 2015.

CSE: Préparation du guide pour la stratification, Rapport intérimaire no. 3, Dakar, Sénégal, 2008.

ELD Initiative: The rewards of investing in sustainable land management. Interim Report for the Economics of Land Degradation Initiative: A global strategy for sustainable land management, The Economics of Land Degradation (ELD) Initiative, available at: www.eld-initiative.org, 2013.

European Commission: Consequences for the ACP Countries of Applying the Generalised System of Preferences (GSP). Europa, Development Analytical Papers for Group 3 on Economy and Trade, European Union, DG VIII, Brussels, 1999.

FAO: FAOSTAT Data, available at: http://faostat.fao.org/ (last access: August 2009), Food and Agriculture Organisation, Rome, 2005.

FAO: Agro-Maps, a global spatial database of sub-national agricultural land-use statistics, In: Land and Water Digital Media Series, vol. 32, FAO, Rome, 2006 
FAO: Gridded Livestock of the World 2007, edited by: Wint, G. R. W. and Robinson, T. P., Rome, 2007.

FAO/IIASA: Global Agro-ecological zones project, Land and Water Digital Media Series 11, FAO, Rome, 2000.

Ferreira, V., Panagopoulos, T., Andrade, R., Guerrero, C., and Loures, L.: Spatial variability of soil properties and soil erodibility in the Alqueva reservoir watershed, Solid Earth, 6, 383-392, doi:10.5194/se-6-383-2015, 2015.

Geng, R., Zhang, G., Li, Z., and Wang, H.: Spatial variation in soil resistance to flowing water erosion along a regional transect in the Loess Plateau, Earth Surf. Process. Landforms, 40, 20492058, doi:10.1002/esp.3779, 2015

Herrick J. E. and Beh, A.: A Risk-Based Strategy for Climate Change Adaptation in Dryland Systems Based on an Understanding of Potential Production, Soil Resistance and Resilience, and Social Stability, in: Sustainable Intensification to Advance Food Security and Enhance Climate Resilience in Africa, edited by: Lal, R., Singh, B. R., Mwaseba, D. L., Kraybill, D., Hansen, D. O., and Eik, L. O., Springer International Publishing Switzerland, Chapter 22, 407-424, 2015.

IFDC: Abuja Declaration on Fertilizer for an African Green Revolution, Africa Fertilizer Summit, African Union Special Summit of the Heads of State and Government, Nigeria, Abuja, 2006.

Izzo, M., Araujo, N., Aucelli, P. P. C., Maratea, A., and Sánchez, A.: Land sensitivity to Desertification in the Dominican Republic: an adaptation of the ESA methodology, Land Degrad. Dev., 24, 486-498, doi:10.1002/ldr.2241, 2013.

Jafari, R. and Bakhshandehmehr, L.: Quantitative mapping and assessment of environmentally sensitive areas to desertification in central Iran, Land Degrad. Dev., doi:10.1002/ldr.2227, online first, 2013.

Jozefaciuk, G. and Czachor, H.: Impact of organic matter, iron oxides, alumina, silica and drying on mechanical and water stability of artificial soil aggregates, Assessment of new method to 30 study water stability, Geoderma, 221-222, 1-10, 2014.

Kairé, M.: Etude de la biodiversité agroforestière dans les agrosystèmes du Bassin Arachidier du Sénégal, Rapport ISRA, 9 pp., 2003.

Kassie, M., Pender, J., Yesuf, M., Kohlin, G., Bulffstone, R., and Mulugeta, E.: Estimating returns to soil conservation adoption in the northern Ethiopian highlands, Agr. Econ., 38, 213-232, 2008.

Keesstra, S. D., Geissen, V., van Schaik, L., Mosse., K., and Piiranen, S.: Soil as a filter for groundwater quality, Curr. Opin. Environ. Sustain., 4, 507-516, doi:10.1016/j.cosust.2012.10.007, 2012.

Keyzer, M. A. and Pande, S.: Classification by crossing and polling for integrated processing of maps and surveys, An addendum to GRCP-software, Centre for World Food Studies of the VU University Amserdam, WP 07-04, 57 pp., 2007.

Keyzer, M. A. and Sonneveld B. G. J. S: Using the mollifier method to characterize datasets and models: the case of the Universal Soil Loss Equation, ITC Journal, 3-4, 263-272, 1998.

Kukal, S. S., Saha, D., Sharma, P., and Sharma, B. D.: Profile distribution of carbon fractions under long-term rice-wheat and maizewheat in alfisols and inceptisols of northwest india, Land Degrad. Dev., doi:10.1002/ldr.2299, online first, 2014.

LADA: Land degradation assessment in Drylands, Land resources, FAO, Rome, Italy, available at: http://www.fao.org/nr/ land/degradation/en/, 2015.
Lal, R.: Soil degradation and food security in South Asia, in: Climate Change and Food Security in South Asia, edited by: Lal, R., Sivakumar, M. V., Faiz, M. A., Mustafizur Rahman, A. H. M., and Islam, K. R., Springer, Dordrecht, the Netherlands, 138152, doi:10.1007/978-90-481-9516-9_10, 2011.

Leiwen, J., Yufen, T., Zhijie, Z., Tianhong, L., and Jianhua, L.: Water resources, land exploration and population dynamics in arid areas - the case of the Tarim River Basin in Xinjiang of China, Popul. Environ., 26, 471-503, 2005.

Masto, R. E., Sheik, S., Nehru, G., Selvi, V. A., George, J., and Ram, L. C.: Assessment of environmental soil quality around Sonepur Bazari mine of Raniganj coalfield, India, Solid Earth, 6, 811821, doi:10.5194/se-6-811-2015, 2015.

Mbow, C., Mertz, O., Diouf, A., Rasmussen, K., and Reenberg, A.: The history of environmental change and adaptation in eastern Saloum - Senegal - driving forces and perceptions, Global Planet. Change, 64, 3-4, 210-221, 2008.

Mortimore, M., Ba, M., Mahamane, A., Rostom, R. S., Serra Del Pozo, P., and Turner, B.: Changing systems and changing landscapes: measuring and interpreting land use transformations in African drylands, Geogr. Tidsskr., 105, 101-120, 2005.

Mulitza, S., Heslop, D., Pittauerova, D., Fischer, H. W., Meyer, I., Stuut, J., Zabel, M., Mollenhauer, G., Collins, J. A., Kuhnert, H., and Schulz, M.: Increase in African dust flux at the onset of commercial agriculture in the Sahel region, Nature, 466, 226-228, doi:10.1038/nature09213, 2010.

Mwango, S. B., Msanya, B. M., Mtakwa, P. W., Kimaro, D. N., Deckers, J., and Poesen, J.: Effectiveness of mulching under miraba in controlling soil erosion, fertility restoration and crop yield in the usambara mountains, Tanzania, Land Degrad. Dev., doi:10.1002/ldr.2332, online first, 2014.

Nelson, A.: African Population Database, UNEP GRID, Sioux Falls, 2004.

Nkonya, E., Pender, J., Kaizzi, C., Kato, E., Mugarura, S., Ssali, H., and Muwonge, J.: Linkages between land management, land degradation and poverty in sub-Saharan Africa: the case of Uganda, IFPRI Research Report No. 159, International Food Policy Research Institute, Washington, DC, 2008.

Ntare, B. R., Diallo, A. T., Ndjeunga, J., and Waliyar, F.: Groundnut Seed Production Manual, International Crops Research Institute for the Semi-Arid Tropics (ICRISAT), Andhra Pradesh, India, 2008.

Omuto, C. T., Balint, Z., and Alim, M. S.: A framework for national assessment of land degradation in the drylands: a case study of Somalia, Land Degrad. Dev., 25, 105-119, doi:10.1002/ldr.1151, 2014.

Pace, G., Vaglio, G., Laurin, L., Do Rosario, P., and Sciortino, M.: Space for the UNCCD and the Desertwatch Project, in: Desertification and Risk Analysis Using High and Medium Resolution Satellite Data, NATO Science for Peace and Security Series C: Environmental Security, edited by: Marini, A. and Talbi, M., Springer in cooperation with NATO Public Diplomacy Division, Dordrecht, the Netherlands, 71-82, 2008.

Rajashekhar Rao, B. K.: Kinetics of potassium release in sweet potato cropped soils: a case study in the highlands of Papua New Guinea, Solid Earth, 6, 217-225, doi:10.5194/se-6-2172015, 2015.

Saito, K., Nelson, A., Zwart, S. J., Niang, A., Sow, A., Yoshida, H., and Wopereis, M. C. S.: Towards a better understanding of bio- 
physical determinants of yield gaps and the potential for expansion of the rice area in Africa, in: Realizing Africa's Rice Promise, edited by: Wopereis, M., Johnson, D., Ahmadi, N., Tollens, E., and Jalloh, A., CAB International, Wallingford, UK, 188-203, 2013.

Singh, K., Mishra, A. K., Singh, B., Singh, R. P., and Patra, D. D.: Tillage effects on crop yield and physicochemical properties of sodic soils, Land Degrad. Dev., doi:10.1002/ldr.2266, online first, 2015.

Stanchi, S., Falsone, G., and Bonifacio, E.: Soil aggregation, erodibility, and erosion rates in mountain soils (NW Alps, Italy), Solid Earth, 6, 403-414, doi:10.5194/se-6-403-2015, 2015.

Sonneveld, B. G. J. S.: Formalizing expert judgments in land degradation assessment: A case study for Ethiopia, Land Degrad. Dev., 14, 347-364, 2003.

Sonneveld, B. G. J. S. and Dent, D.: How good is GLASOD?, J. Environ. Manage., 90, 274-283, doi:10.1016/j.jenvman.2007.09.008, 2007.

Sonneveld, B. G. J. S., Keyzer, M. A., Zikhali, P., and Merbis, M.: National Land Degradation Assessment Senegal and Review of global socio-economic parameters in the LADA data base, Land Degradation Assessment (LADA) project, Report for the FAO, SOW-VU, Amsterdam, the Netherlands, 2010.

Sonneveld, B. G. J. S., Bai, Z., Ndiaye, D., and Bindraban, P. S.: Comparing rainfall use efficiency trends with expert judgments for nation-wide land degradation assessments: the case of Senegal, Journal of Sustainable Development, 5, 116-135, 2012.

Speirs, M. and Olson, O.: Indigenous integrated farming systems in the Sahel, World Bank Technical Paper No. 179, African Technical Department Series, World Bank, Washington, DC, 1992.

Stebbing, E. P.: The encroaching Sahara: the threat to the West African colonies, Geogr. J., 85, 506-524, 1935.

Tesfaye, M.A., Bravo-Oviedo, A., Bravo, F., Kidane, B., Bekele, K., and Sertse, D.: Selection of tree species and soil management for simultaneous fuelwood production and soil rehabilitation in the Ethiopian central highlands, Land Degrad. Dev., 26, 665-679, doi:10.1002/ldr.2268, 2014.

Thomas, C., Sexstone, A., and Skousen, J.: Soil biochemical properties in brown and gray mine soils with and without hydroseeding, SOIL, 1, 621-629, doi:10.5194/soil-1-621-2015, 2015.
Thuo, M., Bravo-Ureta, B. E., Hathie, I., and Obeng-Asiedu, P.: Adoption of chemical fertilizer by smallholder farmers in the peanut basin of Senegal, African Journal of Agricultural and Resource Economics, 6, 1-6, 2011.

Tschakert, P. and Tappan, G.: The social context of carbon sequestration: considerations from a multi-scale environmental history of the Old Peanut Basin of Senegal, J. Arid Environ., 59, 535564, 2004.

UNEP: Senegal Joins the Partnership for Action on Green, available at: http://www.unep.org/greeneconomy/ (last access: September 2014), United Nations Environment Programme (UNEP), Nairobi, Kenya, 2014.

Van Wesenbeeck, C. F. A. and Merbis, M, D.: Data Repository of the Food Economy of Sub-Saharan Africa, Centre for World Food Studies, Amsterdam, 2012.

Vieira, R. M. S. P., Tomasella, J., Alvalá, R. C. S., Sestini, M. F., Affonso, A. G., Rodriguez, D. A., Barbosa, A. A., Cunha, A. P. M. A., Valles, G. F., Crepani, E., de Oliveira, S. B. P., de Souza, M. S. B., Calil, P. M., de Carvalho, M. A., Valeriano, D. M., Campello, F. C. B., and Santana, M. O.: Identifying areas susceptible to desertification in the Brazilian northeast, Solid Earth, 6, 347-360, doi:10.5194/se-6-347-2015, 2015.

Voortman, R. L.: Explorations into African land resource ecology; on the chemistry between soils, plants and fertilizers, $\mathrm{PhD}$ dissertation, VU University Amsterdam, the Netherlands, 2010.

Wang, T., Yan, C. Z., Song, X., and Li, S.: Landsat images reveal trends in the aeolian desertification in a source area for sand and dust storms in China's Alashan plateau (1975-2007), Land Degrad. Dev., 24, 422-429, 2013.

Xu, E. Q. and Zhang, H. Q.: Characterization and interaction of driving factors in karst rocky desertification: a case study from Changshun, China, Solid Earth, 5, 1329-1340, doi:10.5194/se5-1329-2014, 2014.

Yan, X. and Cai, Y. L.: Multi-Scale Anthropogenic Driving Forces of Karst Rocky Desertification in Southwest China, Land Degrad. Dev., 26, 193-200, doi:10.1002/ldr.2209, 2015. 